\title{
The Dynamics of Squid Population in Ternate Island Waters
}

\author{
Umar Tangke ${ }^{1, *}$ Bernhard Katiandagho ${ }^{2}$ \\ ${ }^{1}$ Universitas Muhammadiyah Maluku Utara, Jl. KH. A. Dahlan No. 100, Kel. Sasa, Kec. Ternate Selatan, Terntae- \\ Maluku Utara, Indonesia \\ 2) Akademi Perikanan Kamasan Biak, Biak-indonesia \\ ${ }^{*}$ Corresponding author. Email: umbakhaka@gmail.com
}

\begin{abstract}
Squid, known with scientific name Loligo sp, is a group of cephalopods or a type of Mollusca living in the sea, with horizontal distribution area from coast to open sea and vertical distribution area from sea surface to thousands of meters under sea surface in water column. Until now, squid production still depends on the natural stock since there is no study on technology for its culture, thus it is a concern that if the production keeps increasing, the resource preservation will be threatened. Therefore, for the purpose of sustainable management, it is necessary to study the parameter of population and biomass of squid resource through an analysis on the dynamics of population, including age, growth, mortality and yield per recruit. This research was conducted for 3 months from June - August 2020 aiming at analyzing the parameter of population of squid resource and the exploitation rate in Ternate Island waters using observation method, stock study and population analysis. The research result finds that the squid resource in Ternate Island waters still has stable growth parameters, including maximum length $(\mathrm{L} \infty) 97.13 \mathrm{~mm}$, growth coefficient $(\mathrm{K}) 0.23$ per month, t0 1.26 with total, natural mortality, and catch respectively $0.74,0.50,0.24$ and exploitation rate 0.32 in which these values show lower exploitation rate than expected utilization value of $46.0 \%$.
\end{abstract}

Keywords: Population Dynamics, Loligo Sp, Mortality, Cephalopods.

\section{INTRODUCTION}

The potential of fishery resources in Ternate Island waters is dominated more by wild fisheries and it is one of the waters which greatly contribute to the production of wild fisheries with expected potential of up to 631,703 tons/year with usable amount up to 505,363 tons/year [1]. The types of production of wild fisheries from Ternate Island waters include big pelagic fish, small pelagic fish, demersal fish and non-fish resource including octopus, clam, squid and other fishery resources [1]

Squid, scientifically Loligo sp (Figure 1), is a group of cephalopods or a type of Mollusca with sustainable potential in Ternate Island waters up to 9,664 tons/year and allowed utilization rate of 7,731 tons/years [1]. The squid distribution is generally found from continental shelf area to depth of $200 \mathrm{~m}$ [3]. This wide distribution area influences the wide distribution of catching area from coast to open sea and from area close to sea surface to deep sea. The width of distribution of this catching area causes the rate of utilization or production of squid resource to increase from year to year. The increasing amount of squid resource production is certainly caused by the number of units of catching tool and trip and also the result of side (non-target) catches from the active types of catching tool in the catching operation, such as purse seine and boat lift nets and other catching tools.

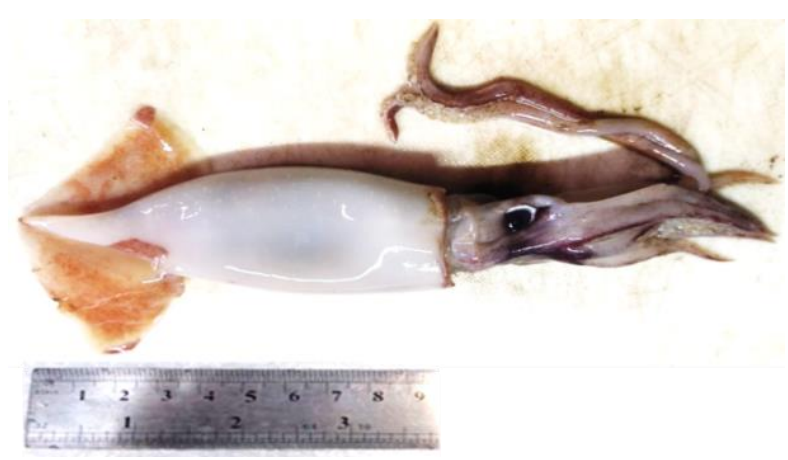

Figure 1 Squid (Loligo $s p$ )

The Indonesian squid production is all derived from catch from the nature and there is no study on technology for its culture [4], including in the Ternate Island waters [1] [5]. Relying only on wild fisheries, there is a concern 
that if the production continuously increases annually, it will threaten the existence and sustainability of squid resource in Ternate Island Waters. Therefore, for the purpose of sustainable management, it is necessary to study on the parameters of population and biomass of squid resource through an analysis on the dynamics of population, including age, growth, mortality, and yield per recruit.

\section{METHOD}

This research was conducted from June-August 2020 with research instruments consisting of digital camera for research sample documentation, HP with 3DMeasurement software for length identification, digital weighing scale for weight measurement and 1 computer unit for data processing and analysis, and research material of squid caught by fishermen of Ternate Island collected daily for 3 months.

\subsection{Data Analysis}

\subsubsection{Length-Weight Relationship}

Length-weight relationship has practice value allowing converting length to weight and vice versa. Squid weight may be deemed as a function of its length, and this length-weight relationship follows cubic law which is represented in the following formula (1) [6].

$\mathrm{W}=\mathrm{a} \mathrm{L}^{\mathrm{b}}$

For parameters $\mathrm{a}$ and $\mathrm{b}$, a regression analysis was employed with $\ln \mathrm{W}$ as $\mathrm{y}$ and $\mathrm{Ln} \mathrm{L}$ as $\mathrm{x}$, the regression equation (2) below is obtained:

$y=a+b x$

A t-test was conducted to study the value of $b=3$ or $\mathrm{b} \neq 3$, with hypothesis:

$\mathrm{H}_{0}: \mathrm{b}=3$, length-weight relationship is isometric.

$\mathrm{H}_{1}: \mathrm{b} \neq 3$, length-weight relationship is allometric, where:

- Positive allometric, if $b>3$ (weight increase is faster than length increase) and

- Negative allometric, if $b<3$ (length increase is faster than weight increase)

\subsubsection{Age Group}

Squid age group is expected using the length frequency method presented by [7] in [8], by dividing squid into some groups of mantle length. This is followed with calculating natural logarithm of the frequency of each mantle length by finding the difference of natural logarithm of calculated frequency ( $\Delta \ln \mathrm{Fc}$ ) among the existing classes. This is followed with mapping of mean value of each mantle length ( $\mathrm{x}$ axis) on difference of the natural logarithm of calculated frequency of squid length (y axis). The intersection of regression straight line with $x$ axis presents average length value of each age group. The average sum of the value of each age group is $a / b$.

\subsubsection{Growth Parameter $\left(L \infty, K, t_{o}\right)$}

The growth model of Von Bertalanffy [8] was employed to examine the growth parameter (3).

$\mathrm{Lt}=\mathrm{L} \infty\left(1-\mathrm{e}^{[-\mathrm{K}(\mathrm{t}-\mathrm{to})]}\right)$

Where:

$\mathrm{Lt}=\quad$ Squid mantle at age $\mathrm{t}(\mathrm{cm})$

$\mathrm{L} \infty=\quad$ Squid asymptote mantle length $(\mathrm{cm})$

$\mathrm{K}=$ Growth rate coefficient (per year)

To $=\quad$ Squid theoretical age at length equal to zero (year)

$\mathrm{T}=$ Age (year)

The empirical equation [9] in [8] was employed to expect theoretical age $\left(\mathrm{t}_{0}\right)$ equal to 0 (zero) as follows (4):

$\log (-$ to $)=0,3922-0,2752(\log \operatorname{L} \infty)-1,038(\log K)$

Where:

$\mathrm{L} \infty=$ Asymptote mantle length

$\mathrm{K}=$ Growth rate coefficient (per year)

$\mathrm{t}_{0}=$ Theoretical age at length equal to zero

\subsubsection{Mortality and Exploitation Rate}

\subsubsection{Catching mortality}

Catching mortality rate $(\mathrm{F})$ is expected using equation (5) and (6) :

$\mathrm{Z}=\mathrm{F}+\mathrm{M}$ (5), thus $F=Z-M$

(6), is obtained

\subsubsection{Total mortality}

Total mortality rate $(\mathrm{Z})$ is calculated using Beveton and Holt formula in [8] as follows (7):

$\mathrm{Z}=\mathrm{K}\left(\frac{\mathrm{L} \infty-\overline{\mathrm{L}}}{\overline{\mathrm{L}}-\mathrm{L}^{\prime}}\right)$

Where:

$\mathrm{K}=$ Growth rate coefficient (per year)

L $\infty=$ Squid asymptote length $(\mathrm{cm})$

$\mathrm{L} \quad=$ Average length of caught squid $(\mathrm{cm})$

$\mathrm{L}^{\prime} \quad=$ lower limit of squid length class size fully caught $(\mathrm{cm})$ 


\subsubsection{3. natural mortality}

Natural morality rate $(\mathrm{M})$ is calculated suing the empirical method [9] as follows (8):

$\mathrm{M}=0.8 * \exp (-0.152-0.270 \ln \mathrm{L} \infty+0.6543 \ln \mathrm{K}+$ $0.4634 \ln \mathrm{T})$

Where:

$$
\begin{array}{lll}
\mathrm{M}= & \text { Natural mortality rate (year) } \\
\mathrm{L} \infty= & \text { Squid asymptote length }(\mathrm{cm}) \\
\mathrm{T}= & \text { Average temperature of water surface }
\end{array}
$$
$\left({ }^{\circ} \mathrm{C}\right)$

The stock exploitation rate (utilization level) was expected using formula (9), [9] in [8]:

$\mathrm{E}=\frac{\mathrm{F}}{\mathrm{F}+\mathrm{M}}=\frac{\mathrm{F}}{\mathrm{Z}}$

Where:

$\mathrm{F} \quad=$ Catch mortality

$\mathrm{Z} \quad=$ Total mortality

$\mathrm{M}$ = Natural mortality

$\mathrm{E}=$ Exploitation rate

\subsubsection{Yield per Recruit}

Yield per recruit (Y/R) was found from Bevertondan Holt equation (10) (11) and (12), [8] below:

$(\mathrm{Y} / \mathrm{R})=\mathrm{E} \cdot \mathrm{Um}\left[1-\frac{3 u}{1+m}+\frac{3 u^{2}}{1+2 m}+\frac{u^{2}}{1+3 m}\right]$

Where:

$$
\begin{aligned}
& \mathrm{U}=1-\frac{\mathrm{Lc}}{\mathrm{L} \infty} \\
& \mathrm{M}=\frac{1-\mathrm{E}}{\mathrm{M} / \mathrm{K}}
\end{aligned}
$$

Explanation:

$\mathrm{E} \quad=$ Exploitation rate

Lc $=$ Smallest class size of fishes caught $(\mathrm{cm})$

M = Natural mortality rate (per year)

$\mathrm{K}=$ Growth rate coefficient (per year)

$\mathbf{L} \infty=$ Fish asymptote length $(\mathrm{cm})$

The research result data were then analyzed using Fisat-II program.

\section{RESULT AND DISCUSSION}

\subsection{Squid production}

According to the data, the squid catch yield in 2019 in Ternate City is $1,926.11 \mathrm{~kg}$ [10]. The data show that the squid production is not maximally utilized by the fishermen. The possible reason of the low production is that the fishermen still use traditional catching tools such as fishing rod, of which mobility is low, and the resource is the side catch of catching tools purse seine and boat lift nets. The squid production in Ternate Island Waters from June-August may be observed in Figure 2.

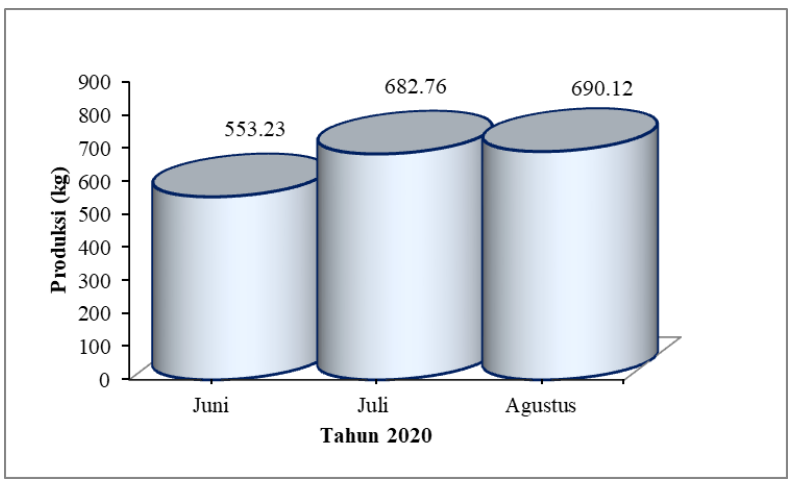

Figure 2 Squid production (Loligo $s p$ ) from JuneAugust 2020

\subsection{Length-Weight Relationship}

There were 553 heads of squid measured as the research samples. From the measurement result, the squid mantle length ranges from 50 - $113 \mathrm{~mm}$ with weight ranging from 20-305.0 gram. The length-weight relationship of squid in Ternate Island Waters is $\mathrm{W}=$ $1.0995 \mathrm{~L}^{0.364 \mathrm{x}}$ with regression coefficient $<3$, which means the allometric growth pattern is negative (Figure 3 ). This growth pattern is similar to the that of squid caught in Java Sea, Arafura Sea and Mumbai Waters/India [11]; [12]; [13]; [14].

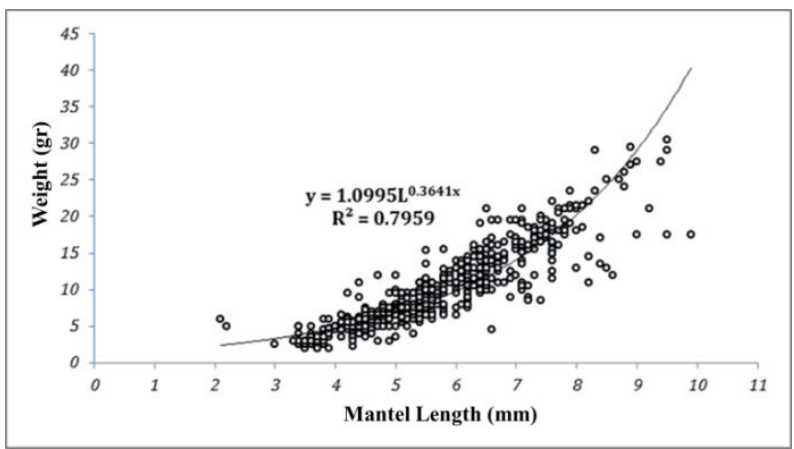

Figure 3 Squid (Lolligo sp) Length-Weight

Relationship

\subsection{Age Group}

Determining age and growth is fundamental in studying the parameter of population of squid resources, in which this study finds initial information of the age structure which may be used to explain the influence of environmental change on growth, survival and factors influencing recruitment success. Knowledge of age group and growth is used to expect the influence of catch on stock, management policy, occurrences in squid life 
cycle and maximum catch yield in consideration of the resource's sustainability [15]. Based on the analysis result, the length of squid in Ternate Island Waters is divided into 5 age groups as presented in Figure 4.

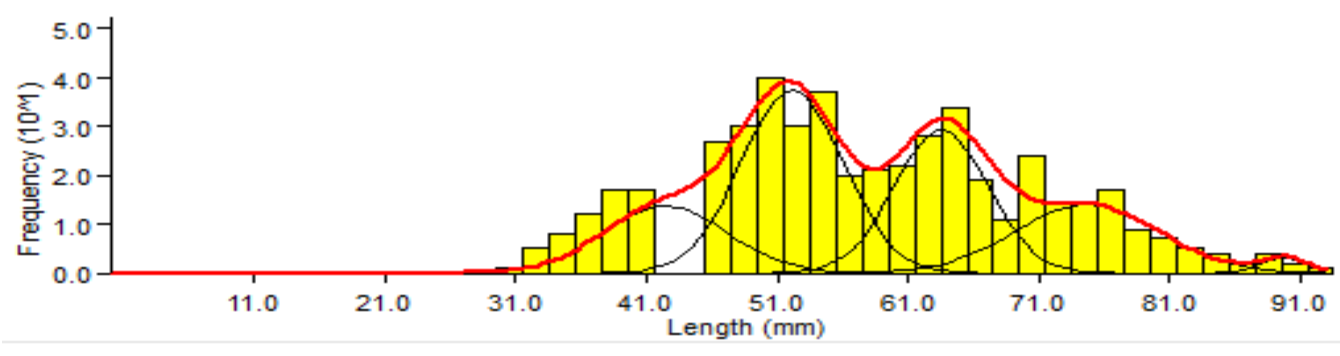

Figure 4 Histogram of the length frequency by normalized squid length class

Based on Figure 4, we may observe that the squid resource caught in Ternate Island Waters has theoretical age of 1 month at length range from $30-41 \mathrm{~mm}$ with average length $36.50 \mathrm{~mm}$, relative age 2 months at length range from 46-66.5 with average length $50.78 \mathrm{~mm}$, relative age 3 months with length range from 5.7-66.5 $\mathrm{mm}$ and average length 60.87 , relative age 4 months at length range from 7.5-84.5 mm with average length 73.52 $\mathrm{mm}$ and relative age 5 months with length range from 8.7-92.5 and average length $87.94 \mathrm{~mm}$.

\subsection{Growth Parameter}

The analysis using Ford Walfrod method [8] by plotting $\mathrm{L}$ value $(\mathrm{t}+\Delta \mathrm{t})$ and $\mathrm{L}(\mathrm{t})$ results in the maximum length value $(\mathrm{L} \infty)$ of squid caught in Ternate Island Waters of $97.13 \mathrm{~mm}$, with growth coefficient (K) 0.23 per month, and $t_{0}$ value 1.26. Based on the $\mathrm{K}, \mathrm{L} \infty$ and $\mathrm{t}_{0}$ values, the equation of the growth of squid (Lolligo $\mathrm{sp}$ ) in Ternate Island Waters is $\mathrm{Lt}=97.13 \mathrm{x}\left(1-\mathrm{e}^{[-0.23(-1.26)]}\right)$. From the growth equation above, we may find the length of squid of various relative ages, the increase of squid length monthly until its asymptote length (Figure 5).

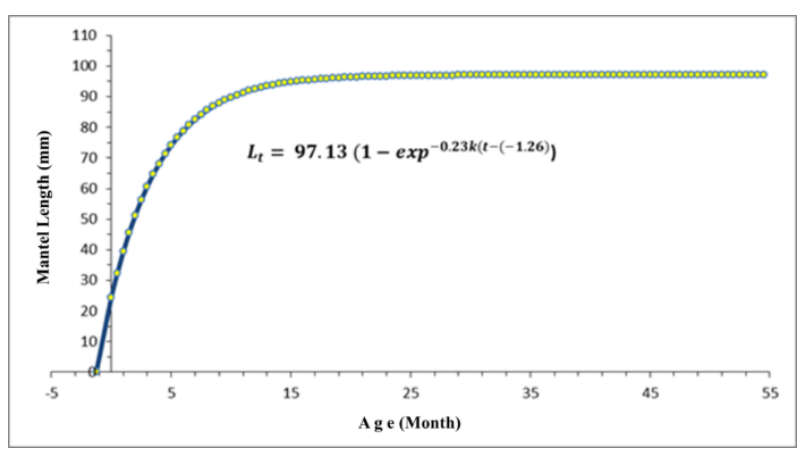

Figure 5 Curve of the growth of squid (Lolligo $s p$ ) in Ternate Island Waters.

From the growth curve in Figure 5, we may observe that in its initial life cycle, squid's growth is relatively rapid and slows down when approaching its maximum length of $97.13 \mathrm{~mm}$. In its entire life, squid living in Ternate Island Waters has low growth rate $(\mathrm{K})(0.23$ per month) that it is lower than $0.5 \mathrm{~cm}$ per year. The squid's maximum length value $(\mathrm{L} \infty)$ is $97.13 \mathrm{~mm}$ and it takes some months to reach its maximum length. This conforms to the statement [8] that with growth rate value or coefficient value $\mathrm{k} \leq 0.5$, one is categorized into resource with slow growth rate and it takes a long time to reach its maximum length. Squid's low growth rate, besides caused by food availability, is expectedly caused by difference in season, temperature and population density. Further, based on the values of parameter of squid growth analyzed, squid's annual recruitment pattern is presented in Figure 6.

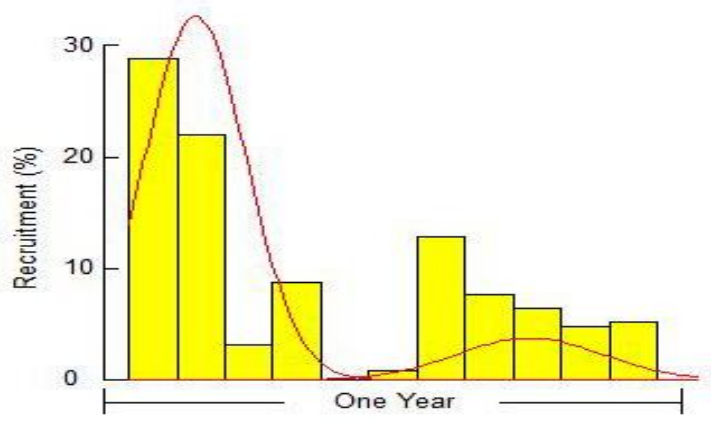

Figure 6 The recruitment pattern of squid (Lolligo $s p$ ) in Ternate Island Waters

\subsection{Mortality and Exploitation Rate}

The mortality of the population of exploited resource is the combination between natural mortality and catch mortality [9]; [8]; [16]. The analysis results in total expected mortality value $(\mathrm{Z})$ of 0.74 and natural mortality $(\mathrm{M})$ by inserting $\mathrm{K}$ value $=0.23$ per month, $\mathrm{L} \infty=97.13$ $\mathrm{mm}$ and average water temperature $29^{\circ} \mathrm{C}$. Figure 7 shows the curve of catch yield for expected $Z$ value, we may observe that the black circle used to calculate $Z$ value based on $\mathrm{R}^{2}$ value in the regression analysis with empty circle is a circle of non-recruited data and exploitation rate value $(E)$ it results in 0.32 per month. Based on Table 2 , we may observe that the values of population parameters of total mortality $(\mathrm{Z})$, natural mortality $(\mathrm{M})$, catch mortality (F) and exploitation ate (E) are respectively $0.74,0.50,0.24$ and 0.32 , differently from the research results [17], with population parameter values consisting of total mortality $(\mathrm{Z})$, natural mortality (M), catch mortality (F) and exploitation rate (E). 


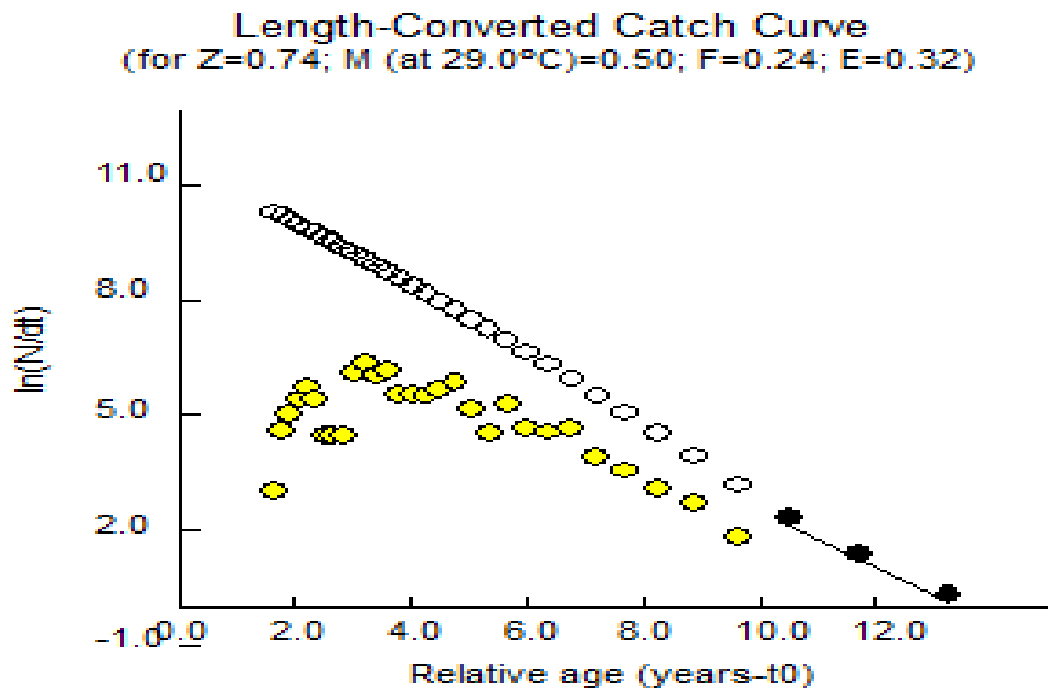

Figure 7 Curve of squid catch yield in Ternate Island Waters

Table 2. Values of the Population Parameter of Squid in Ternate Island Waters

\begin{tabular}{lccc}
\hline \multirow{2}{*}{ Population Parameter } & \multicolumn{2}{c}{ Expected Value (per Year) } & \\
& This Research (2020) & Nursinar, et al. (2015) & Agus (2013) \\
\hline Total Mortality (Z) & 0.74 & 3.1361 & 1.3287 \\
Natural Mortality (M) & 0.50 & 0.0623 & 0.5145 \\
Catch Mortality (F) & 0.24 & 3.0737 & 0.8142 \\
Exploitation Rate (E) & 0.32 & 0.9801 & 0.6128 \\
\hline
\end{tabular}

The natural mortality value is higher than catch mortality value, which means that the squid resource in Ternate Island Waters is mostly not utilized by the fishermen, which is supported by the field condition regarding squid resource utilization, that the fishermen of in Ternate Island Waters generally only use catching tools with low mobility, which is squid fishing tool, with average production per catching tool only up to $2 \mathrm{~kg} /$ Trip, and squid resource is generally only the side catch of purse seine and boat lift nets.
The virtual population analysis describes the dynamics of catch mortality and expected population of each length group. The amount of squid catch population and mortality of each length group is different from each other. The squid's expected biomass in the nature according to VPA analysis is 12.01 ton. Figure 8 presents the graphic of analysis on squid virtual population in Ternate Island Waters.

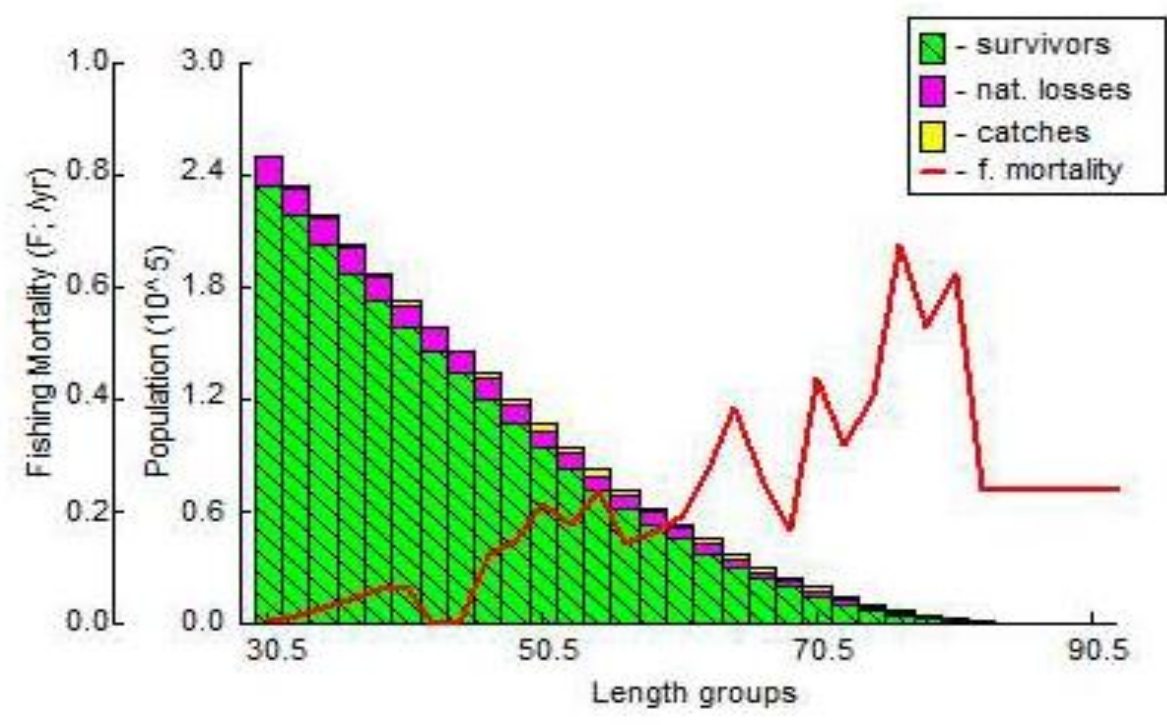

Figure 8 Analysis on the virtual population of squid in Ternate Island Waters. 
According to Figure 8, the squid biomass value in Ternate Island waters is on the mantle length $30.5 \mathrm{~mm}$ up to close to $90.5 \mathrm{~mm}$, in which this amount has natural death rate higher than the amount caught with fishermen's fishing tool. Besides, the catch mortality (F) is higher at mantle length $46.5-80.5 \mathrm{~mm}$.

\subsection{Yield per Recruitment}

The analysis result of yield per relative recruit (Y/R) is designed as the function of $\mathrm{Lc} / \mathrm{L} \infty$ and $\mathrm{M} / \mathrm{K}$, respectively 0.21 and 1.38 with expected $\mathrm{Lc}$ value $=$ $30.5 \mathrm{~mm}$. By inserting $\mathrm{Lc}$ value of $30.5 \mathrm{~mm}, \mathrm{E}_{\max }$ value $=0.523$ per year result in maximum Y/R 0.046 and biomass per recruit at $E_{\max } 0.271$ or $27.1 \%$ of virgin period. Current exploitation rate (Figure 8 ) is $\mathrm{E}=0.23$, in which this value shows that the exploitation rate is lower than the expected utilization value of $46.0 \%$.

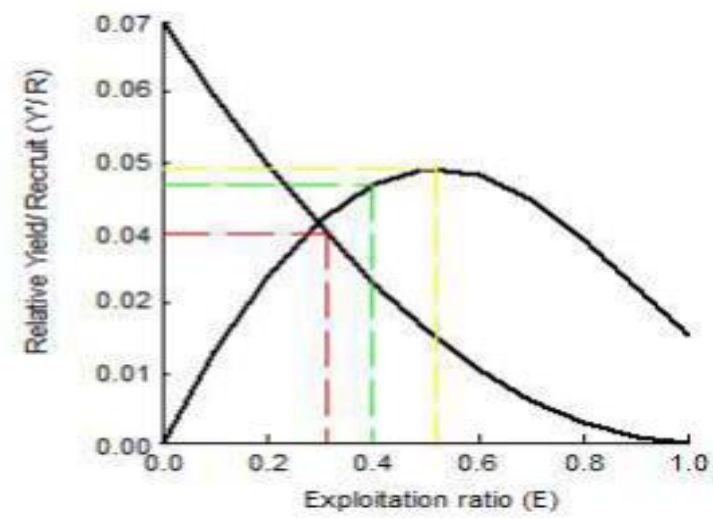

Figure 9 Graphics of catch yield per relative recruitment of squid in Ternate Island waters

Figure 9 shows that the current exploitation rate is still low or a half of optimal exploitation rate, that the current $\mathrm{E}$ value is 0.32 and optimal $\mathrm{E} 0.46$ to produce optimal catch yield 0.043 gram per recruit.

\section{CONCLUSION}

Based on the result of research on some parameters of the dynamics of population, squid (Lolligo $s p$ ) in Ternate Island Waters has population parameters of squid's maximum length $(\mathrm{L} \infty)$ of $97.13 \mathrm{~mm}$ with coefficient $\mathrm{k} \leq$ 0.5 per year of 1.26 with total, natural, and catch mortality values respectively $0.74,0.50,0.24$ and exploitation rate 0.32 , in which this value shows that the exploitation ate is lower than the expected exploitation value $46.0 \%$. The population of squid (Lolligo $s p$ ) in Ternate Island Waters needs attention, especially of the government, with regard to the amount of exploitation, thus it needs attempts to increase the number of catching tools and trips.

\section{REFERENCES}

[1] [DKP], dalam Laporan Dinas Kelautan dan Perikanan Kota Ternate., Produksi Perikanan Tangkap Kota Ternate, Provinsi Maluku Utara, 2019.

[2] Zulham A., Subaryono., Ralph A. Mahulete., Rekomendasi Pengembangan Perikanan Tangkap di Ternate dan Sekitarnya., Depok : PT Raja Grafindo Persada, 2017.

[3] Wulandari D. A, Morfologi, Klasifikasi, dan Sebaran Cumi-Cumi Famili Lolinginidae. J. Oseana, Vol. 43, No. 2, pp. 48 - 65, Okt. 2018.

[4] Theresia S M, Pramonowibowo, Wijayanto D, Analisis bioekonomi perikanan cumi-cumi (Loligo sp.) di Pesisir Kabupaten Kendal, J. of Fisheries Resources Utilization Management and Technology, Vol. 2 , No.3, pp. 100-110, Agus. 2013.

[5] [DKP] Dinas Kelautan dan Perikanan Provinsi Maluku Utara, Statistik Perikanan Tangkap Provinsi Maluku Utara, Prov. Maluku Utara, 2016.

[6] Effendie M. I., Biologi Perikanan, Yogyakarta : Yayasan Pustaka Nusantara, 163 hal. 1997.

[7] Bhattacharya C. G., A Simple Method of resulition, A Distribution into Coasien Component Biometrics.Biometric 23, pp. 115-135, 1974.

[8] Sparre, P. E, Ursin dan S. C. Venema., Introduksi Pengkajian Stock Ikan Tropis. Buku Manual I. FAO, 1999.

[9] Pauly D., A Section Of Simple Method For the Assesment Tropical Fish Stock, FAO, FAO Fisheries Technical Paper (254): 52p. 1980.

[10] PPI Dufa-dufa, Laporan Produksi Tangkapan Ikan dan Nono Ikan di Kota Ternate. Ternate, Maluku Utara, 2020.

[11] Tirtadanua dan Suprapto, Sebaran Cumi-Cumi (Loliginidae) dan Sotong (Sepiidae) yang Tertangkap Trawl di Laut Arafura, Seminar Nasional Pengelolaan Perikanan Pelagis 2016 Marine Resources Exploration and Management (MEXMA) Research Group Fakultas Perikanan dan Ilmu Kelautan, Universitas Brawijaya. 2016.

[12] Ayorbaba A. E., Nurhani Widiastuti, Arnoldus S. Anant, dan Paulus Boli., Biological Aspects of Squids (Loligo sp.) Caught by Fishermen in Manokwari Waters, J. Sumberdaya Akuatik Indopasifik, Vol. 3 No. 1, pp. 65-74, May. 2019.

[13] Puspasari R, dan S. Triharyuni., Karakteristik biologi cumi-cumi di Perairan Laut Jawa, J. Bawal Widya Riset Perikanan Tangkap, Vol. 5, No.2, pp. 103-111, 2013. 
[14] Karnik N.S, S. K. Chakraborty, S.K., Length-weight relationship and morphometric study on the squid Loligo duvauceli (d'Orbigny) (Mollusca/Cephalopoda) off Mumbai (Bombay) waters, West Coast of India," Indian Journal of Marine Sciences, Vol. 30, No. 4, pp. 261-263. 2001.

[15] Ahmad., Penentuan Umur dan Laju Pertumbuhan Cumi-cumi (Sepioteuthis lessoniana) Berdasarkan Analisis Lingkaran Pertumbuhan Harian Pada Statolith, Tesis, Program Pascasarjana Universitas Brawijaya, Malang, 2002.
[16] Welcomme R. L., Inland Fisheries : Ecology and Management. London Fishing News Book. A Divisionof Blackwell Science Publishing, 358p. 2001.

[17] Nursinar S., F. Sahami, dan S. N. Hamzah., Laporan Penelitian. Analisis Dinamika Populasi Suntung (Loligo sp). Pendugaan Beberapa Parameter Dinamika Populasi Cumi-cumi (Sephioteuthis Lessoniana, 1830) yang Tertangkap di Perairan Kota Makassar Sulawesi Selatan, Skripsi, Fakultas Ilmu Kelautan dan Perikanan, Universitas Hasanuddin. Makassar, 2015. 